\title{
Barriers to plantation activities in different agro-ecological zones of Southern India
}

Matilda Palm, Madelene Ostwald, Indu Murty, Rakesh Chaturvedi and N.H. Ravindranath

\section{Linköping University Post Print}

N.B.: When citing this work, cite the original article.

The original publication is available at www.springerlink.com:

Matilda Palm, Madelene Ostwald, Indu Murty, Rakesh Chaturvedi and N.H. Ravindranath, Barriers to plantation activities in different agro-ecological zones of Southern India, 2011, Regional Environmental Change, (11), 2, 423-435.

http://dx.doi.org/10.1007/s10113-010-0154-0

Copyright: Springer Science Business Media http://www.springerlink.com/

Postprint available at: Linköping University Electronic Press http://urn.kb.se/resolve?urn=urn:nbn:se:liu:diva-62931 


\title{
Barriers to plantation activities in different agro-ecological zones of Southern India
}

\author{
Matilda Palm ${ }^{1}$, Madelene Ostwald ${ }^{2,3}$, Indu K Murthy ${ }^{4}$, Rajiv K Chaturvedi ${ }^{4}$ \\ and NH Ravindranath ${ }^{4}$ \\ ${ }^{1}$ Department of Earth Science, Box 460 SE 40530 University of Gothenburg, Sweden \\ ${ }^{2}$ Centre for Climate Science and Policy Research, Linköping University, Norrköping, Sweden \\ ${ }^{3}$ Physical Resource Theory, Department of Energy and Environment, Chalmers University of \\ Technology, Göteborg, Sweden \\ ${ }^{4}$ Centre for Ecological Science, Indian Institute of Science, Bangalore, India
}

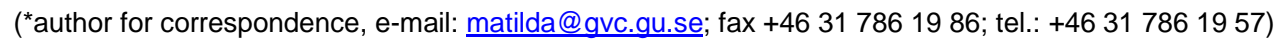

\begin{abstract}
This paper analyses environmental and socio-economic barriers for plantation activities on local and regional level and investigates the potential for carbon finance to stimulate increased rates of forest plantation on wasteland, i.e., degraded lands, in southern India. Building on multidisciplinary field work and results from the model GCOMAP, the aim is to (i) identify and characterise the barriers to plantation activities in four agro-ecological zones in the state of Karnataka and (ii) investigate what would be required to overcome these barriers and enhance the plantation rate and productivity. The results show that a rehabilitation of the wasteland based on plantation activities is not only possible, but also anticipated by the local population and would lead to positive environmental and socioeconomic effects at a local level. However, in many cases, the establishment of plantation activities is hindered by a lack of financial resources, low land productivity and water scarcity. Based on the model used and the results from the field work, it can be concluded that certified emission reductions such as carbon credits or other compensatory systems may help to overcome the financial barrier, however the price needs to be significantly increased if these measures are to have any large-scale impact.
\end{abstract}

Keywords: plantations, agro-ecological zones, carbon finance, CDM

\section{Introduction}

India contains vast tracts of land which are classified as wasteland; these total approximately 64 Mha (NRSA 2005). Wastelands are degraded land, with the degradation process defined as a decline in soil quality with an attendant reduction in biomass productivity and environment moderating capacity i.e. the ability of soil to perform specific functions of interest to humans (Lal 2004). It is estimated that the average Indian wasteland has a biomass productivity of less than $20 \%$ of their overall potential (Ramachandra and Kumar 2003). Despite attempts from the Indian government to reforest the lands through programmes such as the Social Forestry Projects and Joint Forest Management, the current 
rate of plantation is inadequate considering what is required to cover all wastelands within a reasonable timeframe (Ravindranath and Hall 1995).

According to Balooni (2003) the planting of India's wastelands is not only being considered for environmental reasons, but also for the anticipated benefits to the economy. The implementation of plantation projects on wasteland is hampered by social, environmental and economical constraints. Soil degradation processes on wastelands have severely reduced the soil's organic carbon, which is primarily induced by a combination of low biomass productivity and excessive crop residue removals. At the same time, low soil productivity, together with financial difficulties such as a lack of funding and long investment periods are themselves barriers to the implementation of plantation schemes (Ravindranath and Hall 1995; Balooni and Singh 2003). The causes of land abandonment are a complex mix of social, economic and ecological factors (Cramer et al 2007). Overgrazing and fallowing of land, as a result of inadequate rains, drive the land degradation and increase the wasteland areas in Karnataka as well as elsewhere in India.

Following the ideas of the general forest transition model (e.g Mather 1992), India has increased its forest cover from its all time low. This increase can, according to the model, be a result of less dependence on forest resources driven by a more mature economic development. However, in the rural areas of India the dependence on natural resources in general is great, hence the national expansion of forest cover can compete over land that is in demand for other uses, or it can benefit two purposed. In India's submission to the United Nation Framework Convention on Climate Change regarding ways forward for reducing emission from deforestation and forest degradation (REDD), it is proposing a strong conservational component. Due to the national forest circumstances with a halted deforestation and increasing forest cover, India has actively promoted the concept of 'Compensated Conservation'. As a mechanism, India has proposed that REDD should compensate for reducing deforestation as well as I) stabilizing forest cover and II) conserving and increasing forest cover (UNFCCC, 2007). With these circumstances in mind, India will need ecological restoration of less favorable lands to meet the need and ambition that the country has.

The introduction of certified emission reductions, or carbon credits under the Clean Development Mechanism (CDM), or other financial systems such as payment for environmental services or voluntary carbon offsets (Rosa et al. 2003; Taiyab 2005; World Bank 2008) create opportunities and may potentially provide incentives to re-vegetate the wastelands. The mitigation potentials of these financial systems, as well as the environmental and socio-economic factors that influence their realisation are not well known due to the short time span since the emergence of the systems. The carbon market has rapidly gained traction, the questions and the answers related to the implementation of projects and marketplaces have become increasingly important to investors, policymakers and environmentalists (Hamilton 2009). The definition and analysis of possibilities and constraints for plantation projects at both local and regional levels will help policy development by identifying areas where the plantation process may need to be altered or simplified. Albeit a simplification, the use of regional baselines (Sudha et al. 2006) may lead to more approved methodologies and additional registered forestry CDM projects.

Efforts in India to put together plantation projects for CDM, particularly by industries but with local farmer involvement have gained results. During 2009 and 2010 three forestry CDM projects have been registered in India, which make India the country with the most forestry CDM projects (UNFCCC 2009). There are few other projects at different stages of development wherein either abandoned 
agricultural lands or village commons and degraded forest lands are being considered for plantation activities under CDM.

To analyse the potential for plantations on wasteland, based on an agro-ecological zone approach for constraints and potentials of environmental characteristics and socio-economic data, is one method of improving the knowledge in this field, as exemplified by Ravindranath et al. (2007) and that will be adopted in this paper. The paper identifies and analyse environmental and socio-economic constraints for plantation activities on both local and regional scales, with an emphasis on the plantation process and local sustainable development. The potential for wasteland development within the CDM or other financial systems was evaluated by looking at different land uses and various forestry options in four different agro-ecological zones. The land uses chosen are natural forest, plantation, agricultural land, grassland and degraded forestland.

The questions raised are:

- What are the barriers for forest plantations in four agro-ecological zones in Karnataka?

- What would be required to overcome these barriers and thus enhance the rate of plantation and productivity?

- Could the CDM or other financial systems become an instrument for promoting plantation in Karnataka?

\section{Study area}

This study was conducted in the state of Karnataka in southwest India. The geographical area of Karnataka is about 19.05 Mha, of which roughly 3.06 Mha (i.e., 16\%) is covered with forest. India has a diverse pattern of temperature, rainfall, soil, vegetation type and socio-economic conditions and has adopted the principles of agro-ecological zoning (FAO 1981; FAO 1996). This study uses the FAO agro-ecological zone classification, which is based on the length of growing period concept. This, in turn, is derived from climate, soil and topography data and evaluated using a water balance model and knowledge about crop requirements. The agro-ecological zone (hereafter referred to as the zone) approach has been globally adopted for assessing the growth potential of crops and can also be extended to the growth of forest or plantation biomass. The use of zone classification for this assessment is logical due to the geographical differences that greatly influence the potential of any plantation activity. India has categorised its entire geographic area into 20 zones, four of which will be included in this study (Figure 1): zones 3, 6, 8, and 19 (Table 1).

\section{Figure 1 somewhere here}

\section{Table 1 somewhere here}

The state of Karnataka is diversified, not only when it comes to the physical geography but also with respect to its climate characteristics. The four zones differ in both precipitation and available water capacity. The diverse rainfall pattern is not only dependent on the season - the area receives $80 \%$ of its rainfall during the southwest monsoon period - there are also geographical differences, with the costal zone (19) receiving more than $1700 \mathrm{~mm} / \mathrm{year}$, while zone 3 on the central plateau receives only $1200 \mathrm{~mm} /$ year. 


\section{Approach and methodology}

\subsection{Collection and processing of land-use data}

District wasteland data for the years 1994 and 2001 were collected from the National Remote Sensing Agency (NRSA 1998; NRSA 2005) to obtain the total extent of wasteland in Karnataka. The collected data was later compared with historical data to analyse the current wasteland development. The plantation rate was estimated based on the annual area planted under different species as reported by Karnataka Forest Department annual reports (KFD 2003). The carbon uptake rates of above ground biomass and increases in soil organic carbon were compiled from a survey of the available literature for the given zones as well as for different plantation management systems, in this case long and short rotation plantations (Ravindranath et al. 2000; Ravindranath et al. 2006). Biomass growth rates and soil carbon uptake rates for different zones and different plantation management options (short rotation, 7 years and long rotation, 40 years) were compiled from the literature (Prasad et al. 1987; Ravindranath et al. 1992; Ravindranath et al. 2000).

\subsection{Stakeholder interviews on wasteland use and future potential}

The semi-informal interviews with key informants were conducted to assess the socio-economic factors affecting the usage of the wastelands (Mikkelsen 1998). One key informant from each village was participating in the study, eight in total. The key informant was either the chairman of the village forest committee or a person in a leading position in the village. The aim of the interviews was also to assess the availability of land for plantation purposes from a local perspective, to receive information regarding the usage of the existing forest from the people directly influenced by a plantation project and finally, to estimate the potential for the villagers to play an active role in such a project. The interviews consisted of a set on fixed questions and possibilities to informal conversation. Amongst all the interviews provided information about how the villages viewed the plantation projects and their willingness to be involved in further development projects. Potential areas for plantation projects were also selected. The land quality in selected areas varied from rather good to bad within the wasteland categories. A total of 17 wasteland areas ${ }^{1}$ were assessed, together with nine plantations ${ }^{2}$ and two areas consisting of natural forest land and agricultural land. The plantations were further sub-divided into old and new plantations

\subsection{Assessment of wasteland quality}

\subsubsection{Soil}

Soil samples were collected and United States Department for Agriculture (USDA) vegetation and erosion assessments (USDA 1993) were conducted during field work to determine the environmental features of the wasteland. The soil samples were collected from a total of 56 plots, identified by the key informants measuring 50x50 m, with up to four plots in each land-use. A total of five different landuse systems were investigated, giving 336 individual soil samples altogether. Three pits, $30 \mathrm{~cm}$ in depth, were dug to collect $200 \mathrm{~g}$ samples at two depths in each pit, one at 0-15 cm and one at 15-30 $\mathrm{cm}$, giving six samples from each plot. The samples were aggregated to composite samples, one for each depth and each land-use, resulting in 48 samples. They were analysed for carbon content using

\footnotetext{
${ }^{1}$ Grassland (some partly cultivated), degraded natural forest and degraded plantations.

${ }^{2}$ Cashew, Eucalyptus, Mango, Indian Gooseberry.
} 
the Walkely-Black method, nitrogen $(\mathrm{N})$ using the Kjeldahl method, phosphorous $(\mathrm{P})$ using the Olsen method, cation exchange capacity ${ }^{3}$ and particle size (Landon 1991). The particle size distributions were measured and expressed in the form of the sand:silt:clay ratio (Table 2 defined according to the USDA soil texture classes (USDA 2002), The soil texture can be used to determine the relationship between land use and the available water capacity (AWC) (NMSU 1996).

\subsubsection{The USDA vegetation and erosion assessment}

The USDA vegetation and erosion assessment is a visual interpretation and assessment, conducted to gain knowledge about the quality of the land including existing vegetation, erosion and physical characteristics such as soil cover and measures to preserve the soil. The assessment was categorised into six classes, $0,0-24,25-49,50-74,75-99$ and $100 \%$ where the parameters evaluated was: erosion, ground vegetation, shrub vegetation, crown cover and soil cover (USDA 1993). The plots were mapped, i.e. measured, systematically drawn on a scale of 1:500 and photographed. The different classes were used to compare different land-use systems in terms of the percentage of erosion, ground vegetation, shrub vegetation, crown cover and soil cover.

\subsection{Assessment of financial incentives using GCOMAP}

To estimate the future investment necessary for plantation implementation and the effect of those investments on the plantation rate, the Generalized Comprehensive Mitigation Assessment Process (GCOMAP) model was used (Sathaye 2005). Sathaye (2005) describe the model as a dynamic partial equilibrium model built to simulate the response of the forestry sector to changes in future carbon prices. The general equilibrium models mostly rely on a few global data sets. One goal of the GCOMAP model is to make use of detailed country-specific activity, demand, and cost data available to the authors on mitigation options and land use change by region. The model establishes a baseline scenario that has no financial revenues from carbon (US $\$ 0$ per $\mathrm{tC}$ ) and represents the current plantation rate in different zones upon which the future development is based. Using this as a starting point, areas under plantation for carbon mitigation, the overall mitigation activity and the potential for the period 2005-2100 was assessed. The input data for the model are presented in table 2. GCOMAP simulates the response of uses of forest and wasteland to changes in the carbon price at different plantation rates and estimates the amount of additional land brought under the mitigation activity above the baseline level.

\section{Table 2 somewhere here}

Three additional carbon price cases (US $\$ 5,50$ and 100 per tC) were considered in this assessment. The carbon price used in the baseline scenario represents a present-day approximate carbon price from voluntary projects, where voluntary forest credits range from $6.3-7.7 \mathrm{US} \$ / \mathrm{t} \mathrm{CO}_{2}$ equivalents, including projects of afforestation/reforestation plantations, afforestation/reforestation conservation, forest management and avoided deforestation (Hamilton et al. 2009). The other two price scenarios are higher and more in line with the European Union emission trading level which have varied between 10-15 US\$ for 2009 (ECX 2009). The carbon monitoring cost was set to US $\$ 1 /$ ha/year and applied to all the carbon pricing scenarios except for the baseline, where no carbon monitoring was required.

\footnotetext{
${ }^{3}$ Cation exchange capacity (CEC) can be used as a measure of the fertility of the soil. A high CEC is considered favourable as it contributes to the capacity of the soil to retain plant nutrient cations (Landon 1991).
} 


\section{Result}

\subsection{Land-use pattern in the agro-ecological zones}

Approximately 1.4 Mha of the total area in the state of Karnataka has been identified as land which is potentially available for plantation projects, representing $7.1 \%$ of the total wasteland (NRSA 2005). This area was included in the model as potential land for plantation projects, with distribution among the four zones based on their percentage of the total area (Table 3).

\section{Table 3 somewhere here}

Based on Karnataka Forest Department annual reports it is estimated that 1.6 Mha of land was planted in the state of Karnataka up to 2004. Of this, approximately $12 \%$ of the plantations fell under long rotation management, while $88 \%$ was planted under short rotation management. The same proportion of available potential land was allocated to different options in different zones under the assumption that this trend will continue.

Compiled literature data from across Karnataka suggests that plantations established on wasteland have considerably lower biomass growth rates than natural forests or plantations on private land. For instance, in zone 8 , the biomass productivity in plantations on wasteland varied from 1.4 to $1.7 \mathrm{t} / \mathrm{ha} / \mathrm{yr}$ with a mean of $1.55 \mathrm{t} / \mathrm{ha} / \mathrm{yr}$, while they were considerably higher in plantations on farm land i.e., in agro-forestry, where the productivity varied from $4-11.1 \mathrm{t} / \mathrm{ha} / \mathrm{yr}$ with a mean of $7.55 \mathrm{t} / \mathrm{ha} / \mathrm{yr}$. The natural forest in zone 19 had a mean productivity of $4.85 \mathrm{t} / \mathrm{ha} / \mathrm{yr}$, according to our references (Prasad et al. 1987; Ravindranath et al. 1992; Ravindranath et al. 2000).

\subsection{Environmental and socioeconomic barriers and incentives - a stakeholders perspective}

During the interviews, the eight key informants identified several barriers to, and merits for the establishment of plantation activities on their land. The issues discussed were not ranked, however pointed out several times. The villagers identified lack of water and soil quality concerns, meaning that the plantations would use too much of the already scarce water resources in the villages as well as extract nutrients from the soil needed for other crops. However, the erosion rate would decreases after the establishment of a plantation, the infiltration capacity increases and the plantations contribute to better local climates which are clear incentives for a potential implementation of a plantation project. The villagers point out that plantation projects on privately owned plantations on wasteland are welcomed by the villagers whilst the experience shows that plantations introduced by the government are occupying too vast an area of the village. The results also indicate that the plantations already established in the villages do not have the same soil quality as the natural forest.

When the key informants were asked for their opinion and experience regarding plantations projects and their possible involvement in such a project their response was more or less similar regardless of the geographical location. Many of the villages have had negative experiences of governmental plantations, where neither the revenues nor the harvest have benefited the locals. However, previous plantation activities have increased the rate of employment in the villages. Even though the villagers do not manage these plantations themselves the accessibility of forest products increases with the establishment of plantation activities. The villagers state that they are interested in, and have the 
capacity to invest their time and devote land to an eventual plantation project, as they see a plantation on the wasteland as an investment for future needs. The villagers would prefer a mixed plantation with natural species and would like to receive an income, as well as pulp and fruit yield from a potential plantation on the wasteland. Such a project would ideally be locally rooted and managed by the villagers. However, financial resources are scarce in the villages and the funding needed for the establishment plantation projects are not locally available.

\subsection{Wasteland quality}

\subsubsection{Soil}

The results of the soil analysis (Table 4) show the differences in soil organic carbon, nitrogen, phosphorous and cation exchange capacity and clay content between the different land-use systems. All the investigated parameters have lower mean values in wastelands than in the natural forests. The plantations have a higher soil organic carbon mean value, cation exchange capacity and clay content than the wastelands.

\section{Table 4 somewhere here}

The carbon content, cation exchange capacity and clay content are higher in the plantations than in the wastelands of zones 6 and 8 . In contrast, all parameters in zone 3 are lower in the plantations in comparison to those in the wasteland. The results show that the old plantations have higher values for all parameters than the newly established plantations, with the exception of phosphorus. The old plantations also exceed the values of wasteland for all parameters except phosphorous. When the newly-established plantations are compared to wasteland, only the cation exchange capacity and the clay content are higher in the plantations. This could illustrate the poor quality of the land where plantations are established.

Given the sand:silt:clay ratio the wasteland and plantations are classified as sandy clay loam and the natural forest as clay loam. The soil texture can be used to determine the relationship between land use and the available water capacity for the different sampled areas in this study. The soil texture analysis shows that the wasteland and plantation categories have an average available water capacity of $154 \mathrm{~mm} / \mathrm{m}$ soil (Table 3), while the natural forest category has an average available water capacity of $188 \mathrm{~mm} / \mathrm{m}$ soil.

Table 5 shows that the natural forest is significantly different in terms of organic carbon and nitrogen both to the plantations and the wasteland. The wasteland is significantly different in terms phosphorous compared to the plantations. The same relationship can be seen when newly established plantations are being compared to older plantations. In AEZ 8 all the parameters show a significantly difference between the plantations and the wasteland. The result indicates no relationship between land use and CEC levels confirming Saikh's et al. (1998) measurement in Orissa, India.

Table 5 somewhere here 


\subsubsection{USDA}

The USDA analysis divides the wasteland category into grassland and degraded forest land and compares the result with those for plantations and agricultural land (Table 4). It also gives an assessment of the environmental barriers and potential for plantation activities. The grasslands and the degraded forests show a high degree of erosion and have less soil cover than other land-use systems. The degraded forests hold some tree cover, but not enough to be defined as a forest under the rules and regulations of the CDM. The grassland has a small amount tree or shrub cover. This makes the grassland ideal for plantation establishment, since no vegetation needs to be cleared prior to the plantation. The impact of erosion on the land is low or non-existent where some kind of land management has taken place, such as plantation or agriculture. The USDA analysis shows that the wastelands with largest areas of erosion are located in zones 6 and 19, which have a total of $10 \%$ erosion in each zone (Figure 2).

\section{Figure 2 here somewhere}

\subsubsection{Climate}

The climate data, mean temperature and total precipitation, compiled from the National Centers for Environmental Prediction Reanalysis data base (NCEP 2006), show an increasing trend in the mean air temperature, about $0.5-1^{\circ} \mathrm{C}$ over a period of approximately 60 years, from $1946-2005$ (Figure 3). The change is largest in the two districts with the lowest mean annual temperature: zone 8 on the inland plateau and zone 19, the coastal area. The two zones with the highest mean annual temperature have experienced a smaller increase over these years. The precipitation pattern over the same period shows a decreasing trend in all four zones, most noticeably in zone 19 with a decrease of $500 \mathrm{~mm}$ and around $160-170 \mathrm{~mm}$ over this period in the other zones. Zones 6 and 8, however, showed increased precipitation in a later part of the period. This data does not indicate minimum and maximum values, i.e., the variability which may have a direct bearing on vegetation.

\section{Figure 3 somewhere here}

\subsection{Assessment of carbon price incentives}

Figure 4 shows the rate of plantation activities with different carbon price scenario model runs according to the GCOMAP model. An increase in the carbon price from 0 in the baseline to 5,50 or US $\$ 100 \mathrm{per} \mathrm{t} / \mathrm{C}$ sequestered would, as expected, increase the plantation rate. For all the zones, the rate of plantation activities would be higher for a short rotation management period than for a long rotation management period, regardless of the carbon price. The increase is larger in zones 6 and 8 than in zones 3 and 19 for the entire period. The difference in the planted area between zones 6 and 8 is more than twice the planted area in zone 3 . For the short rotation option in zone 8 , a maximum planted area of $0.3 \mathrm{Mha}$ is reached by the year 2100 (carbon price level US $\$ 100 / \mathrm{tC}$ ). The results show that with US\$100/tC all the wasteland will be under plantation prior to the year 2100 .

\section{Figure 4 somewhere here}

Increases in the carbon price from 0 to US $\$ 5 / \mathrm{tC}$ would only create marginal increases in land area planted. The largest increase in land under plantation activities by the year 2100 was obtained at this price for the short rotation option in zone 6, where the increase from the baseline scenario is 6740 ha. The smallest increase (2500 ha) was obtained for the short rotation option in zone 19. 


\subsection{Illustrative recommendation for a possible CDM strategy}

The illustrative results of this study make it is possible to give recommendations for a potential CDM strategy (or other financial systems) in the state of Karnataka. The current carbon price situation seems to be insufficient as an incentive for the establishment of plantation projects. Higher prices or additional incentives are required. The zone approach can be useful in feasibility studies and evaluations of plantation activities. The four zones considered in this study show several similarities when it comes to both climate and socio-economical factors. The interviews show that plantation activities are welcome and needed in all four zones. A future increased temperature, lack of financial resources and limited water availability are the main barriers to the establishment of plantation projects. The wasteland availability, USDA, GCOMAP, soil quality and available water capacity local socio-economy and finally local barriers analyses reveal were incorporated in a comparative table to resent recommendations regarding future plantation projects. Depending on the requirements for a plantation project, different zones will be more or less suitable. For example, the results from the USDA analysis show that zone 6 is most affected by erosion in comparison to zone 8 , where erosion is a minor problem. The results from the analysis regarding, USDA, GCOMAP, soil quality, AWC, for plantation

Plantation activities can either aim at wasteland rehabilitation, preferably targeting areas in zone 6 , or aim at maximising productivity, which would mean targeting areas in zone 8 . When the available water capacity is taken into account, zone 19 appears to be the most favourable and zone 8 the least favourable. An evaluation of all parameters investigated, including the carbon content, cation exchange capacity and clay content, would point to zone 8 , having significant potential for rehabilitation According to the GCOMAP results, zones 6 and 8 seem most favourable since an increased carbon price would result in the highest increase in the plantation rate. A synthesis of the results of the different analyses point to zone 6 as the preferable zone for plantation activities, followed by zones 8 (Table 5) and 19, with zone 3 being the least suitable.

\section{Table 6 somewhere here}

The analyses carried out in this study confirm the degraded state of wastelands, with low productivity and hence low incentive for usage. Overcoming the environmental barriers will require large investments. In addition to the financial barrier at the local level, water shortages and low land productivity are also important factors which limit plantation activities.

\section{Discussion}

According to the NRSA (NRSA 2005), the availability of wastelands in this area is substantial. However, poor land quality and low water availability are two of the greatest environmental barriers to plantation projects in the area, as indicated by the results. Plantation projects can facilitate soil rehabilitation and enhance the soil carbon content show several experiments with well selected trees and intensive management on severely degraded Indian wastelands (Sing 1990; Mishra et al. 2003; Pal and Sharma 2001). When the plantations in this thesis are being compared to the wasteland there is a clear indication that soil quality improves with time arguing for long term plantation projects. This indicates that plantations on wastelands would indeed increase the productivity of the lands and improve the general environmental status. However, even a slight increase in vegetation cover from the baseline can be beneficial for restoration the wasteland in terms of erosion control and an 
increasing of the organic matter. The modelling conducted in this study is based on eucalyptus and acacia plantations which are very often not the preferred alternatives of the local communities. Depending on the local need, a mixed plantation or agro-forestry is the preferred options, even if exotic species such as acacia may be highly valued for certain purposes. The data from the plantations analyzed in this study is collected in field and are a mixture of fruit species and fast-growing species.

Water is currently scarce in Karnataka, particularly in the eastern parts. The climate in the recent past shows an increase in temperature and a decrease in rainfall. If the increasing trend in temperature and the partly decreasing trend in precipitation continue in the future, the implications are a drier and warmer climate in the entire state. The lack of water is already a problem when establishing new plantations. In a country such as India, which is dependent on season-regulated monsoons, there is an even higher pressure on land management schemes aimed at an increasing infiltration and decreasing surface run-off. If an increase in the productivity of the wasteland is to be achieved then improved land management is necessary, with water conservation as the main goal. All possible practices, such as increasing soil organic matter, clay content and cation exchange capacity are necessary for a sustainable water resource management. One option to increase the infiltration rate and reduce runoff is to increase the vegetation cover or implement soil management practices such as ditching and countering of gully formation. However, to increase the productivity on wastelands further, initial supplement of nutrients and organic matter may be necessary (Ravindranath and Hall 1995; Olsson and Ardö 2002).

One of the major socio-economic barriers to current and future plantation activities is the lack of financial resources. The same barriers can be shown from projects worldwide (Zhou et al. 2007). Lack of funding is one major constraint. The investments required for wasteland rehabilitation may be too large for small scale farmers. Joshi (1997) shows that many farmers consider a rotation period of 7-10 years too long in relation to their revenue needs and are therefore unwilling to invest. The modalities of the forestry CDM where the carbon credits can be issued for temporary credits may be one way of getting around this problem. Involving a larger group of farmers may be another way forward, where the risk could be spread and common resources shared during the years where no revenue was obtained from the plantations.

The GCOMAP analysis shows that forestry CDM or other compensatory systems could be one way of overcoming some of the financial constraints illustrated in the results. Thus, a higher carbon price incentive is necessary to bring larger areas under plantation in the near future. Other options for financing plantation activities could be found in voluntary carbon projects with carbon credits presented to the voluntary market (World Bank 2008; Taiyab 2005; Hamilton 2009) or payment for environmental services (PES). The concept of PES is based on compensation to land holders for the protection or production of environmental services. These services could include an option to ensure climate change mitigation at the lowest cost, an option to ensure environmental services of local or regional interest such as the regulation or filtration of water flows and a possibility to strengthen rural livelihoods and revalue rural landscapes, their diversity of practices and ecosystems (Rosa et al. 2003).

It should be observed that the GCOMAP model only returns general/regional results; it cannot be reduced to a local/district scale without carefully examining the potential at the local level. As seen in the interviews, some of the key informants highlight several environmental barriers for plantation implementation. Local conditions must always be taken seriously since they are determining the failure or success of plantation implementations. Generally, it can be concluded that the villagers are not 
satisfied with the outcome of the government-introduced plantations, which only led to a small amount of employment and poor revenues. At the same time, several key informants describe multiple cobenefits that would follow the establishment of new plantations under a private regime. Perez et al. (2007) conclude that the introduction of a financial system for carbon trading should never be forced on local communities by regional, national or global institutions. The importance of local farmers' participation in plantation management and species selection is illustrated in a paper by Blay et al. (2008). By consulting the participants, the local people's needs were identified. This minimized the differences in interest and encouraged greater participation.

Since the reforestation of wasteland generates benefits for the public good from local to global level, it could be argued that some of the costs should be covered by national means or international aid (FAO 2006). To some extent, this is already happening in India, with its large reforestation program. A market mechanism was selected in this study as a complement to the national efforts. Using a market mechanism as an incentive to establish plantations on wasteland requires strong and well-developed institutions to ensure a flow of financial benefits to the locals involved. The well-established Joint Forest Management programme has developed institutions that empower and enable local communities to participate effectively in forest management to some extent. These institutions could be adjusted to suit a financial flow based on a market mechanism (Ravindranath et al. 2003). Previously, institutions such as the JFM have failed on certain occasions due to the fact that the returns from these plantations were very low and communities in some cases lost access to grass and fuelwood when plantations were introduced and its closure during the initial years. However with a carbon incentive, communities have a stake in the maintenance of these plantations and therefore the local institutions would take active interest in maintaining sinks. Given that the wastelands in question support very low biomass for use as fuelwood or fodder, raising of plantations that would provide incentives will motivate the local communities to maintain the sinks created, provided they are made aware of the benefits of maintaining sinks.

The wastelands in this study are in most cases unsuitable for agricultural purposes and would instead be better suited to plantation purposes; however, this does not mean that this is still the only option for land-less farmers to generate an income. To obtain a comprehensive picture of the different alternatives, several analyses need to be carried out, for example a cost-benefit analysis, a land suitability investigation and an eligibility analysis for different financial options. The rising concerns over land-use competition, food vs. fuel or mitigation, should not be taken lightly (Tenenbaum 2008, Runge and Senauer, 2008, Naylor et al., 2007, Pingali et al. 2008). However, while Runge and Seanuer (2008), and Naylor et al. (2007) both recognize that the right policies could curb this risk. The land competition issue will play a major role in determining the availability of land for plantations in the future (Ravindranath et al. 2009).

\section{Conclusion}

The results of this study led to the following conclusions:

- Water is currently scarce in Karnataka. The climate in the recent past shows an increase in temperature and a decrease in rainfall, which implies that less water will be available in the future. If an increase in the productivity of the wasteland is to be achieved then improved land management is necessary, with water conservation as the main goal. 
- The major socio-economic constraint for establishing plantation activities on wasteland is the lack of financial resources, despite a wealth of interest and experience. In many cases, high investment costs and long rotation periods obstruct the establishment of financially beneficial plantation activities.

- Financial opportunities such as the CDM or other compensatory systems could possibly help to overcome financial constraints. At a carbon price of US $\$ 5 / \mathrm{tC}$, the area planted would be marginal; hence the price has to increase to bring about an improvement on present plantation rate.

- The parameters addressed in this assessment is not exhausted, i.e. do not cover every aspect of relevance, which is primarily due to the complexity of the situation regarding land use in this environment, including both environmental hardship, climate variability, poverty aspects and development parameters. However, the method highlights several components of each of these parameters but acknowledge that other input data can be used.

- Area-specific results such as the ones presented here can be used as guidance in feasibility studies for plantation projects.

\section{Acknowledgements}

Funding for this research was provided by the Swedish Energy Agency, the Knut and Alice Wallenberg foundation and Stiftelsen för Internationalisering av Högre Utbildning och Forskning (STINT). We gratefully acknowledge the Indian Institute of Science, Bangalore. The authors also wish to thank Martin R Jepsen, Lars-Ove Westerberg, Göran Berndes and Deliang Chen for their invaluable comments on the manuscript.

\section{References}

Balooni K, Singh K (2003) Financing of wasteland afforestation in India. Natural Resource Forum $27 p$ 235-246

Balooni K (2003) Economics of wasteland afforestation in India, a review. New Forest 26 101-136

Blay, D., Appiah M, Damnyaq L, Dwomoh FK, Lukkanen O and Pappinen A (2008) Involving local farmers in rehabilitation of degraded tropical forests: some lessons from Ghana. Environment, Development and Sustainability 10:503-518

Cramer VA., Richard JH. and Standish RJ.(2007) What's new about old fields? Land abandonment and ecosystem assembly. Trends in Ecology \& Evolution 23:2, 104-112

ECX (2009) The European climate exchange. Monthly reports September 2009. Available at: http://www.ecx.eu/media/pdf/ecx\%20monthly\%20report\%20-\%20september\%202009.pdf Retrieved October 2009 
FAO (1981) Report on the Agro-ecological Zones Project (1978-1981), Vol. 1: Methodology and Results for Africa. World Soil Resources Report 48/1. Rome

FAO (1996) Agro-Ecological Zoning: Guidelines FAO soil bulletin - 73

FAO (2006) Global Forest Resources Assessment 2005. Progress towards sustainable forest management. FAO Forestry Paper 147, 320 pp.

Hamilton K, Sjardin M, Shapiro A and Marcello T (2009) Fortifying the Foundation, State of the Voluntary Carbon Markets 2009. A Report by Ecosystem Marketplace \& New Carbon Finance

Joshi PK (1997) Farmers' investments and government intervention in salt-affected and water logged soils. In Kerr, JM., Marothia, D.K., Singh, K., Ramasamy, C., Bentley, W.R., (Eds.) Natural Resource Economics: Theory and Application in India. Oxford \& IBH Publishing Co., New Delhi/Calcutta, pp. 403-420

KFD (2003) Karnataka Forest Department Annual Report 1996-1997 to 2002-2003 (5 volumes), Forest Department, Government of Karnataka

Lal R (2004) Soil Carbon Sequestration in India. Climatic Change 65: 277-296

Landon JR (1991) Booker tropical soil manual. New York: Longman Scientific \& Technical.

Mather, A. (1992). The forest transition. Area 24:367-379

Mikkelsen B (1998) Methods for development work and research - a guide for practitioners. Sage Publications

Mishra A, Sharma S D and Khan G.H., (2003) Improvement in physical and chemical properties of sodic soil by 3, 6 and 9 years old plantation of Eucalyptus tereticornis Biorejuvenation of sodic soil. Forest Ecology and Management 9(184):115-124.

Naylor, R., Liska, A., Burke, M., Falcon, W., Gaskell, J., Rozelle, S., Cassman, K. (2007). The Ripple Effect: Biofuels, Food Security, and the Environment. Environment, 49(9): 30-43.

NCEP (2006) Earth System Research Laboratory, Physical Science Division, Climate Analysis Branch, http://www.cdc.noaa.gov/ Retrieved June 2006

NMSU (1996) New Mexico State University, http://weather.nmsu.edu/irrdoc/soilfc.html Retrieved August 2006

NRSA (1998) Wastelands Atlas of India. Government of India, Ministry of Rural Development, National Remote Sensing Agency, New Delhi and National Remote Sensing Agency, Dept. of Space, Government of India, Balanagar, India. 
NRSA (2005) Wastelands Atlas of India. Government of India, Ministry of Rural Development, National Remote Sensing Agency, New Delhi and Remote Sensing Agency, Dept. of Space, Government of India, Balanagar, India.

Olsson L, Ardö J (2002) Soil Carbon Sequestration in Degraded Semiarid Agroecosystems - Perils and Potential, Ambio, 31, 471-477

Pal R.C. and Sharma A, (2001) Afforestation for reclaiming degraded village common land: a case study. Biomass and Bioenergy 7(21):35-42

Pingali, P., Raney, T., Wiebe, K. (2008). Biofuels and Food Security: Missing the Point. Review of Agricultural Economics, 30(3): 506-516.

Prasad SN, Hegde HG, Bhat DM, Hegde M (1987) Estimation of Standing biomass and productivity of tropical moist forests of Uttar Kannada district, Karnataka, India. CES Technical report 19. Centre for Ecological Sciences, Indian Institute of Science

Ramachandra, Kumar (2003) Wastelands: rehabilitation and management approaches. Leisa India, December 2003

Ravindranath NH, Somashekar HI, Shailaja R, Parthasarathy CK, Jagdish KS (1992) Study of tree plantation resources in a semi arid region of Karnataka. Energy Environment Monitor 8(2):71-77.

Ravindranath NH, Hall DO (1995) Biomass, Energy and Environment - A developing country perspective from India, Oxford and IBH Publishing Co. Pvt. Ldt

Ravindranath NH, Murali KS, Malhotra KC (2000) Joint forest management and community forestry in India, Oxford and IBH Publishing Co. Pvt. Ldt, New Delhi

Ravindranath NH, Murthy IK, Sudha P, Sahana CA (2003) Clean Development Mechanism and Joint Forest Management programme in India. Indian Forester, 129(7)

Ravindranath NH, Murthy IK, Chaturvedi RK, Andrasko K, Sathaye AJ (2006) Carbon price driven mitigation potential of forestry sector in India. Special Issue on Estimation of Baselines and Leakage in Carbon Mitigation Forestry Projects, Published By International Energy Studies

Ravindranath N.H., Murth I.K., Sudha P., Ramprasad V., Nagendra M.D.V. and Sahana C.A. (2007) Methodological issues in forestry mitigation projects: a case study of Kolar district. Mititgation and Adaptation Strategies for Global Change 12:1077-1098

Ravindranath N.H, Mauvie R., Fargione J., Canadell J.G., Berndes G., Woods J., Watson H. and Sathaye J. (2009) Greenhouse Gas Implications of Land Use Change and Land Conversion to Biofuel Crops. In Biofuels: Environmental Consequences and Interactions with Changing Land Use. Proceedings of the Scientific Committee on Problems of the Environment (SCOPE) International Biofuels Project Rapid Assessment eds. Howarth R.W. and Bringezu, S 
Rosa H, Kandel S, Dimas L (2003) Compensation for Environmental Services and Rural Communities - Lessons from the Americas and Key Issues for Strengthening Community Strategies. PRISMA

Runge, F., Senauer, B. (May/June 2007). How Biofuels Could Starve the Poor. Foreign Affairs, 86(3).

Saikh H, Varadachari C and Ghosh K (1998) Effects of deforestation and cultivation on soil CEC and contents of exchangeable bases: A case study in Simlipal National Park, India Plant and Soil 204: $175-181$

Sathaye J, Makundi W, Dale L, Chan P, Andrasko K, (2005) GHG Mitigation Potential, Costs and Benefits in Global Forests: A Dynamic Partial Equilibrium Approach. Ernest Orlando Lawrence Berkeley National Laboratory LBNL-58291

Singh B (1990) Rehabilitation of alkaline wasteland on the gangetic alluvial plains of Uttar Pradesh, India, through afforestation, in Land Degradation and Development 5(1):305-310

Sudha P, Das S, Khan H, Hedge GT, Murthy IK, Shreedhara V, Ravindranath NH (2006) Regional baseline for the dominate agro-ecological zone in Karnataka, India. Special Issue on Estimation of Baselines and Leakage in Carbon Mitigation Forestry Projects, Published By International Energy Studies

Taiyab N (2005) Exploring the Market for 'Development Carbon' through the voluntary and retail sectors. International Institute for Environment and Development (IIED)

Tenenbaum DJ (2008) Food vs. Fuel: Diversion of crops could cause more hunger. Environmental Health Perspective 116:6

Thornthwaite C W (1948) An approach toward a rational classification of climate. Geographical Review, 38: 55-94.

UNFCCC. 2007. SBSTA 26th session Bali, 3-11 December 2007. Views on issues related to further steps under the Convention related to reducing emissions from deforestation in developing countries: approaches to stimulate action. FCCC/SBSTA/2007/MISC.14/add.2

UNFCCC (2009) CDM project activities. Available at: http://cdm.unfccc.int/Projects/index.html Retrieved October 2009

USDA (1993) Soil Survey Manual. Handbook No 18. Washington DC. United States Department of Agriculture

USDA (2002) Field Book for Describing and Sampling Soils Version 2.0 National Soil Survey Center Natural Resources Conservation Service U.S. Department of Agriculture

World Bank the, IETA (2008), State and trends of the carbon market. The World Bank and the International Emission Trading Association (IETA) 
Zhou S, Yin Y, Xu W, Ji W, Caldwell I and Ren J (2007) The costs and benefits of reforestation in Liping County, Guizhou Province, China Journal of Environmental Management, 85(3):722-735 


\section{Figures}

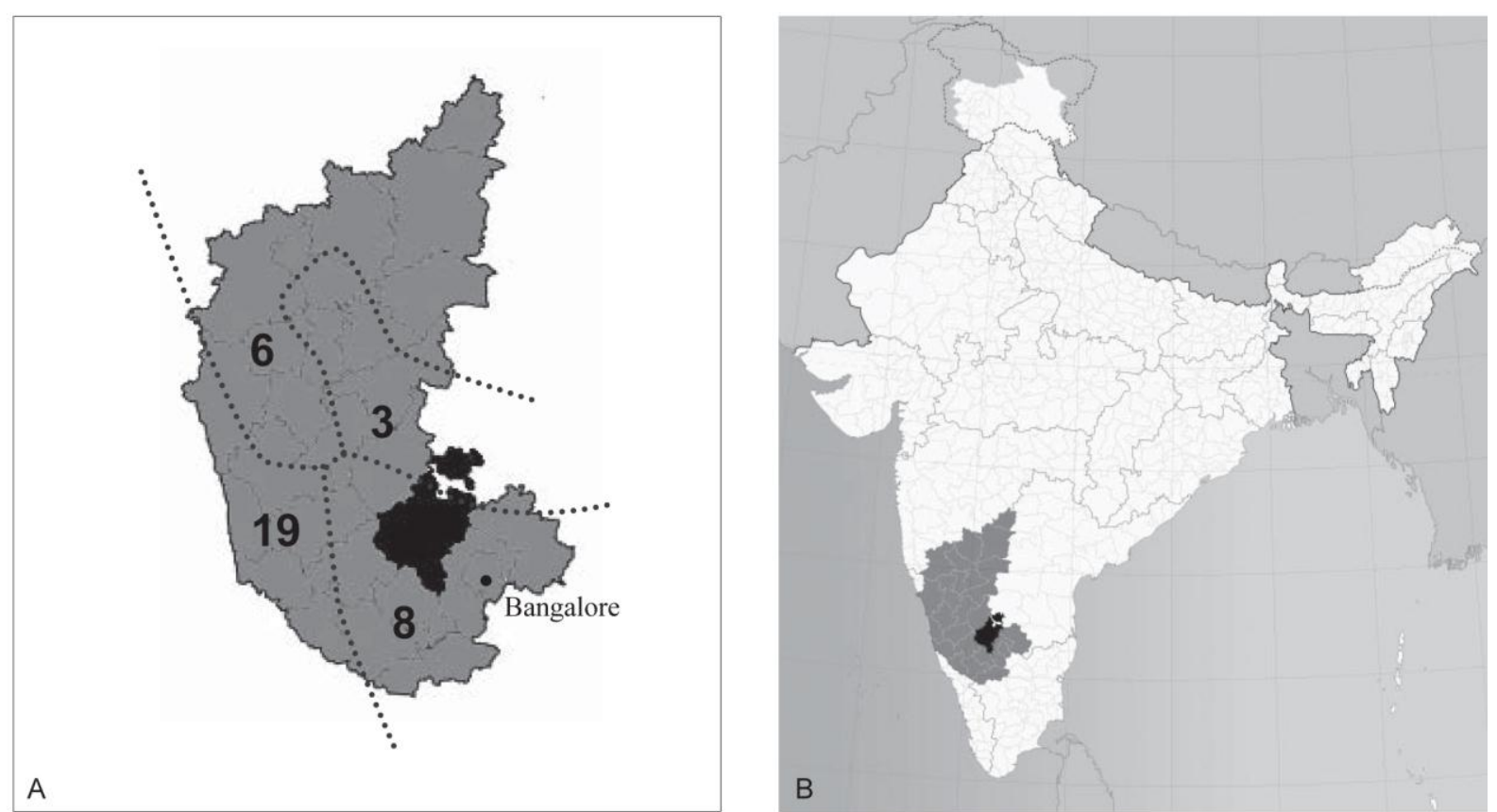

Figure 1. Figure 1 (A) Map of Karnataka state with Tumkur district highlighted. Agro-ecological zones of Karnataka area marked in the map. (B) The map shows India and the location of Karnataka state and Tumkur district. 


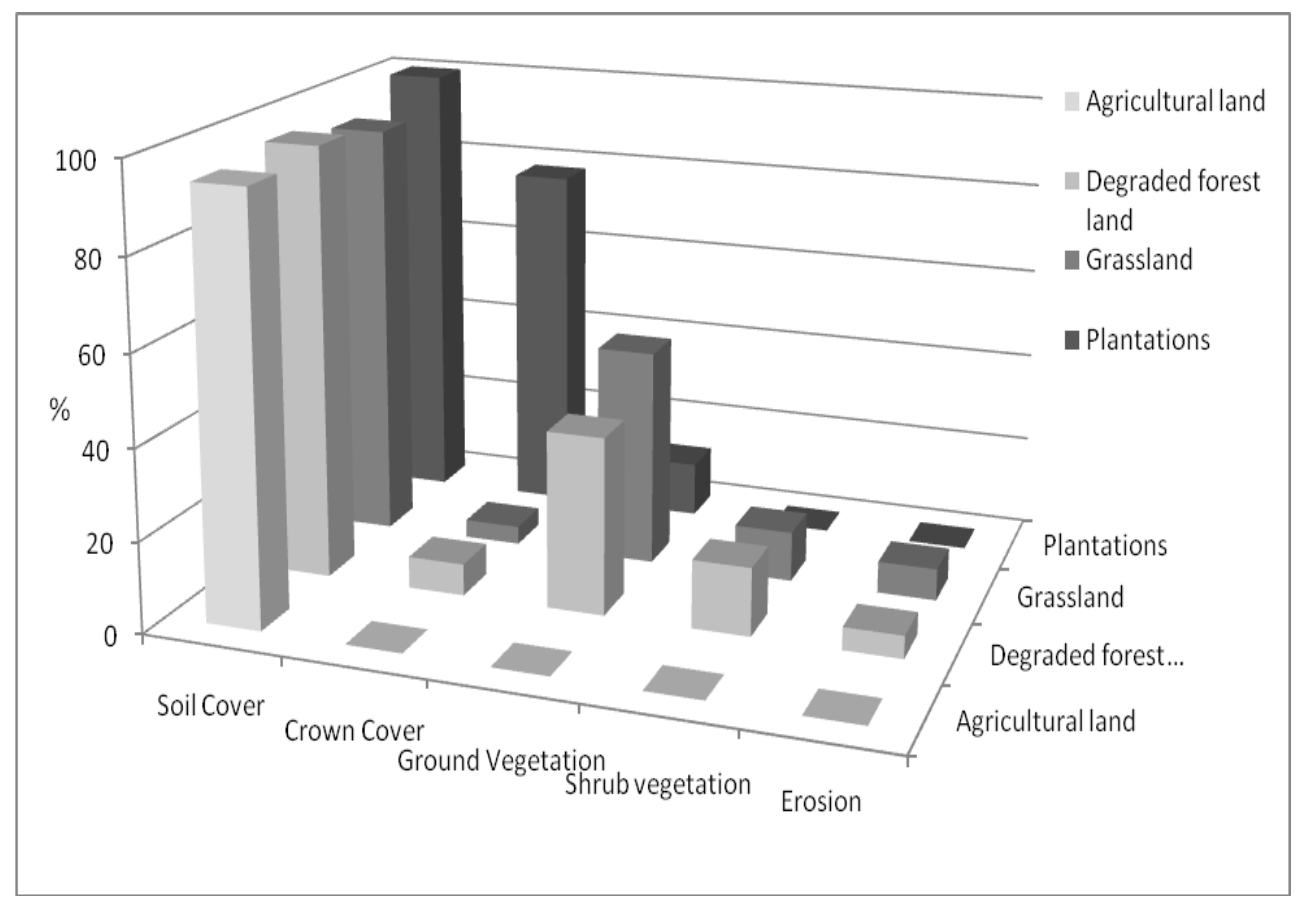

Figure 2. Results from the USDA vegetation and erosion assessment. The results of the USDA analyses are expressed in percentage (USDA 1993). 


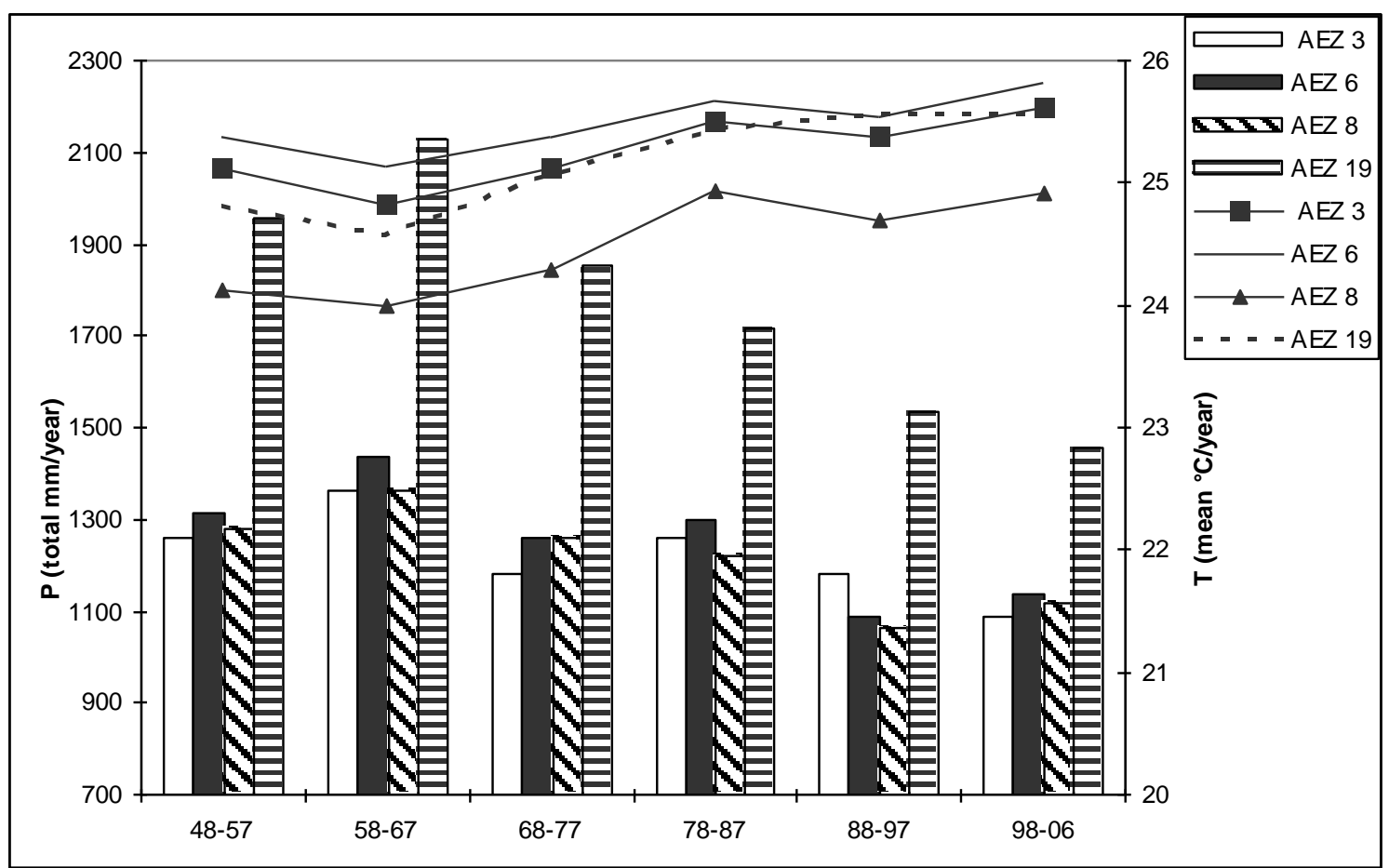

Figure 3. Total precipitation and mean temperature in agro-ecological zones 3, 6, 8 and 19 in Karnataka in 10-year periods between 1948 and 2006 (except between 1998 and 2006, which is only nine years). Source data NCEP 2006. 

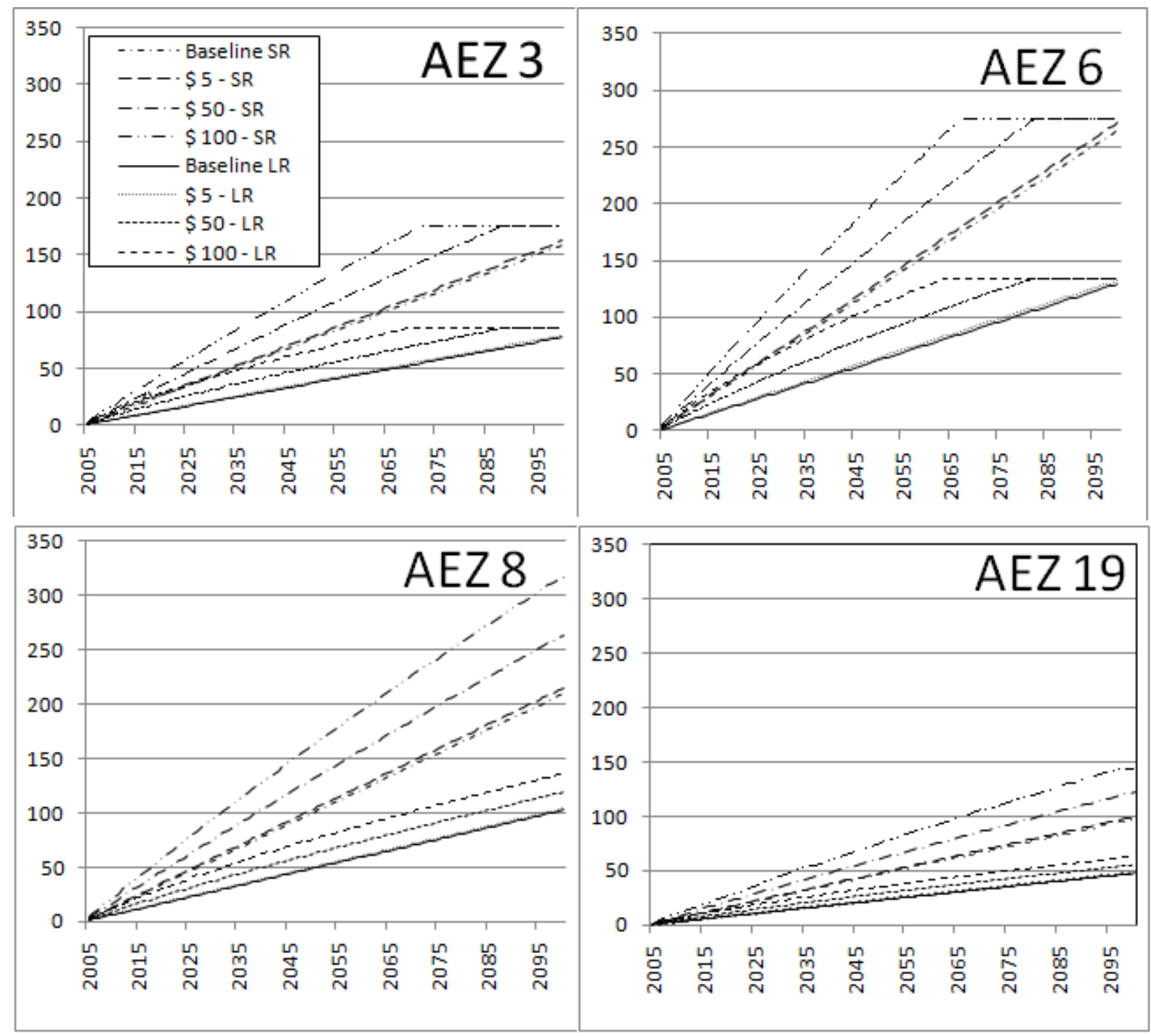

Figure 4

The amount of land area brought under plantation activities under short rotation and long rotation in agro-ecological zones 3, 6, 8 and 19 under different carbon price scenarios with GCOMAP modeling. $\mathrm{SR}$ - short rotation and LR - long rotation. 


\section{Tables}

Table 1. Climate, soil, length of growing period (LGP) and available water holding capacity (AWC) characteristics of the four agro-ecological zones (AEZ) for the state of Karnataka, India.

\begin{tabular}{ccccc}
\hline Characteristics & AEZ 3 & AEZ 6 & AEZ 8 & AEZ 19 \\
\hline Climate & Hot arid & $\begin{array}{c}\text { Hot dry semi- } \\
\text { arid and hot dry } \\
\text { sub humid }\end{array}$ & $\begin{array}{c}\text { Hot moist semi- } \\
\text { arid }\end{array}$ & Hot perhumid $^{*}$ \\
\hline Soils (FAO) & $\begin{array}{c}\text { Vertisols and } \\
\text { Lexisol }\end{array}$ & Vertisols & Lexisol & Nitosols \\
\hline LGP (days) & $60-90$ & $\begin{array}{c}90-120 \\
150-180\end{array}$ & $120-150$ & $240-270$ \\
\hline AWC & Low to medium & Medium to high & Low & Low
\end{tabular}

Moisture index over 100, i.e., available water exceeds the potential levels of evapotranspiration (Thornthwaite 1948). 
Table 2. Following data were collected at zone level.

\begin{tabular}{lll}
\hline Area data & Biomass and soil carbon data & $\begin{array}{l}\text { Cost for carbon } \\
\text { stock monitoring }\end{array}$ \\
\hline $\begin{array}{l}\text { Annual land area planted (short } \\
\text { rotation and long rotation) }\end{array}$ & $\begin{array}{l}\text { Standing vegetation and mean annual } \\
\text { increment of biomass }\end{array}$ & $\begin{array}{l}\text { Yearly monitoring } \\
\text { cost per ha: US } \$ 1^{*} .\end{array}$ \\
$\begin{array}{l}\text { Wotal available land } \\
\text { Land area available for }\end{array}$ & $\begin{array}{l}\text { Initial soil carbon stock and soil carbon } \\
\text { mitigation activities. }\end{array}$ & \\
& accumulation rate \\
& Litter as \% of mean annual increment \\
& Decomposition period \\
& $\%$ mean annual increment as timber \\
& Harvest categories and \% timber & \\
& Wood waste \\
& Fuel wood and harvest residue. &
\end{tabular}

* The cost of 1 US\$ per ha for yearly monitoring reflect the actual operational cost as experienced in the field in Indian conditions (Ravindranath et al 2007).

Table 3 The development of different wasteland areas during the period 1998 to 2001 in different agroecological zones (AEZ). The areas are presented in hectares.

\begin{tabular}{llllll}
\hline Characteristics & Year & Grassland & $\begin{array}{l}\text { Degraded } \\
\text { forestland }\end{array}$ & Other & Total \\
\hline AEZ 3 & 1998 & 66228 & 137048 & 1431 & $\mathbf{2 0 4 7 0 7}$ \\
\% change & 2001 & 66907 & 135731 & 8717 & $\mathbf{2 1 1 3 5 5}$ \\
\hline AEZ 6 & & 1 & -1 & 609 & $\mathbf{3}$ \\
\hline \% change & 1998 & 276077 & 238739 & 9743 & $\mathbf{5 2 4 5 5 9}$ \\
\hline AEZ 8 & 2001 & 180010 & 139431 & 21707 & $\mathbf{3 4 1 1 4 8}$ \\
\% change & & -35 & -42 & 223 & $\mathbf{- 3 5}$ \\
\hline AEZ 19 & 1998 & 424302 & 315914 & 43366 & $\mathbf{7 8 3 5 8 2}$ \\
\% change & 2001 & 180330 & 219911 & 21285 & $\mathbf{4 2 1 5 2 6}$ \\
\hline
\end{tabular}

Other land-uses include gullied and ravinous land, shifting cultivation, degraded pasture and grazing land, degraded land under plantation and mining or industrial land. These lands together make up less than $10 \%$ of the total area and are therefore not described in more detail (NRSA 2005). 
Table 4. The results from the soil analysis divided into different land-use systems in different agroecological zones (AEZ) in Karnataka. The wasteland category includes grassland and degraded forestland.

\begin{tabular}{|c|c|c|c|c|c|c|c|c|c|}
\hline Larameter & $\begin{array}{c}\text { Organic } \\
\text { C\% }\end{array}$ & $\begin{array}{c}\text { Nitrogen } \\
\%\end{array}$ & $\begin{array}{c}\text { Phos- } \\
\text { phorus } \\
\text { ppm }\end{array}$ & CEC & sand & ticle size & clay & $\begin{array}{c}\text { Soil } \\
\text { texture } \\
\star\end{array}$ & $\begin{array}{l}\text { AWC } \\
\mathrm{mm} / \mathrm{m}\end{array}$ \\
\hline \multicolumn{10}{|l|}{ AEZ mean } \\
\hline $\mathrm{NF}_{(n=2)}$ & $1.1(0.14)$ & $0.27(0.04)$ & 38 (24.61) & $9.2(0.26)$ & $37(1.14)$ & $30(3.43)$ & $32(2.29)$ & $\mathrm{CL}$ & 188 \\
\hline$W(n=34)$ & $0.37(0.19)$ & $0.13(0.05)$ & $28(9.87)$ & $8.4(3.46)$ & $61(16.11)$ & $15(1.13)$ & $24(8.66)$ & SCL & 154 \\
\hline$P(n=18)$ & $0.42(0.18)$ & $0.12(0.04)$ & $24(6.14)$ & $9.5(2.03)$ & $62(20.16)$ & $12(8.38)$ & $\begin{array}{l}25 \\
(14.83)\end{array}$ & SCL & 154 \\
\hline $\operatorname{Old}^{* *}(\mathrm{n}=8)$ & $0.49(0.22)$ & $0.14(0.05)$ & $20(6.40)$ & $9.6(0.66)$ & $48(15.06)$ & $20(6.81)$ & $\begin{array}{l}32 \\
(11.09)\end{array}$ & SC & 171 \\
\hline$N e W^{* *}(n=10)$ & $0.37(0.13)$ & $0.10(0.02)$ & $26(5.05)$ & $9.4(2.44)$ & $57(23.49)$ & $15(9.03)$ & $\begin{array}{l}28 \\
(17.71)\end{array}$ & SCL & 154 \\
\hline \multicolumn{10}{|l|}{ AEZ 3} \\
\hline$W(n=8)$ & $0.45(0.21)$ & $0.11(0.03)$ & $23(12.13)$ & $13.2(3.48)$ & 47 (18.34) & $\begin{array}{l}29 \\
(14.95)\end{array}$ & $24(3.46)$ & $\mathrm{L}$ & 169 \\
\hline$P(n=2)$ & $0.17(0.21)$ & $0.08(0.06)$ & $14(8.69)$ & 7.9 (3.35) & $68(21.62)$ & $13(7.57)$ & $19(9.64)$ & SL & 118 \\
\hline \multicolumn{10}{|l|}{ AEZ 6} \\
\hline$W(n=8)$ & $0.39(0.21)$ & $0.14(0.34)$ & $27(4.00)$ & $8.9(1.41)$ & $63(10.90)$ & $11(3.05)$ & $26(8.44)$ & SCL & 154 \\
\hline$P(n=12)$ & $0.44(0.21)$ & $0.11(0.03)$ & $25(5.69)$ & $10(2.37)$ & $50(23.96)$ & $16(9.09)$ & $\begin{array}{l}33 \\
(16.59)\end{array}$ & SC & 171 \\
\hline \multicolumn{10}{|l|}{ AEZ 8} \\
\hline$W(n=10)$ & $0.25(0.12)$ & $0.07(0.04)$ & 35 (11.15) & $5.5(2.22)$ & $75(13.46)$ & $9(5.84)$ & $16(8.44)$ & SL & 118 \\
\hline$P(n=4)$ & $0.51(0.16)$ & $0.15(0.05)$ & $25(4.45)$ & $9.4(0.50)$ & $53(3.20)$ & $21(7.77)$ & $26(8.01)$ & SCL & 154 \\
\hline \multicolumn{10}{|l|}{ AEZ 19} \\
\hline $\mathrm{NF}_{(\mathrm{n}=2)}$ & $1.1(0.14)$ & $0.27(0.04)$ & $38(24,61)$ & $9.2(0.26)$ & $37(1.14)$ & $30(3.43)$ & 32 (2.29) & $\mathrm{CL}$ & 188 \\
\hline$W(n=8)$ & $0.55(0.15)$ & $0.19(0.04)$ & $32(6.60)$ & $9.1(0.97)$ & $51(5.40)$ & $17(5.82)$ & $33(7.21)$ & SC & 171 \\
\hline
\end{tabular}

${ }^{*}$ CL: Clay Loam, SC: Sandy Clay, L: Loam, SCL: Sandy Clay Loam, SL: Sandy Loam

AWC source (NMSU 1996)

** Old plantation implies plantations older than 10 years and new plantation implies plantations younger than 10 years 
Table 5. Statistically significant differences between soil characteristics in different land use from field work in Karnataka

\begin{tabular}{|c|c|c|c|c|c|c|c|}
\hline \multirow{2}{*}{ Land use } & \multirow[b]{2}{*}{ Org. C } & \multirow[b]{2}{*}{ Nitrogen } & \multirow[b]{2}{*}{ Phosphorus } & \multirow[b]{2}{*}{ CEC } & \multicolumn{3}{|c|}{ Particle size } \\
\hline & & & & & Sand & silt & clay \\
\hline \multicolumn{8}{|c|}{ AEZ total } \\
\hline NF $-\mathbf{W}$ & $0.019^{* *}$ & $0.022^{\star *}$ & 0.836 & 1.0 & $0.045^{\star *}$ & 0.112 & 0.112 \\
\hline NF - P & $0.023^{\star *}$ & $0.023^{* \star}$ & 0.38 & 0.8 & 0.53 & $0.044^{* *}$ & 1.0 \\
\hline$P-W$ & 0.61 & 0.743 & $0.019^{* *}$ & 0.459 & $0.087^{*}$ & 0.37 & 0.11 \\
\hline P old - P new & 0.15 & $0.073^{*}$ & $0.076^{\star}$ & 0.93 & 0.47 & 0.21 & 0.475 \\
\hline P old - W & 0.22 & 0.49 & $0.012^{* *}$ & 0.501 & $0.063^{*}$ & 0.11 & $0.04^{\star *}$ \\
\hline \multicolumn{8}{|c|}{ AEZ 3} \\
\hline $\mathbf{W}-\mathbf{P}$ & 0.147 & 0.115 & 0.295 & 0.115 & 0.296 & 0.296 & 0.60 \\
\hline \multicolumn{8}{|c|}{ AEZ 6} \\
\hline $\mathbf{W}-\mathbf{P}$ & 0.393 & 0.243 & 0.56 & 0.297 & 0.12 & 0.165 & 0.123 \\
\hline \multicolumn{8}{|c|}{ AEZ 8} \\
\hline $\mathbf{W}-\mathbf{P}$ & $0.034^{* *}$ & $0.06^{*}$ & $0.034^{* \star}$ & $0.005^{\star *}$ & $0.011^{\star \star}$ & $0.024^{\star *}$ & $0.09^{*}$ \\
\hline \multicolumn{8}{|c|}{ AEZ 19} \\
\hline W - NF & $0.036^{\star \star}$ & 0.063 & 1.0 & 0.29 & 0.04 & 0.068 & 0.79 \\
\hline \multicolumn{8}{|c|}{ Wasteland } \\
\hline AEZ 3 - AEZ 6 & 0.673 & 0.672 & 1.0 & $0.016^{\star \star}$ & $0.059^{*}$ & $0.093^{*}$ & 0.294 \\
\hline AEZ 3 - AEZ 8 & $0.075^{\star}$ & $0.011^{* *}$ & 0.155 & $0.002^{* *}$ & $0.006^{\star *}$ & $0.041^{* *}$ & 0.11 \\
\hline $\begin{array}{l}\text { AEZ } 3-A E Z \\
19\end{array}$ & 0.313 & 0.004 & 0.207 & $0.016^{\star *}$ & 0.172 & 0.115 & $0.036^{\star *}$ \\
\hline AEZ 6 - AEZ 8 & 0.328 & $0.001^{* *}$ & 0.014 & $0.004^{\star *}$ & $0.051^{*}$ & 0.286 & $0.021^{* *}$ \\
\hline $\begin{array}{l}\text { AEZ } 6-A E Z \\
19\end{array}$ & 0.103 & $0.008^{\star *}$ & 0.318 & 0.208 & $0.036^{\star *}$ & $0.027^{\star *}$ & 0.248 \\
\hline $\begin{array}{l}\text { AEZ } 8-A E Z \\
19\end{array}$ & $0.002^{\star *}$ & $0.000^{* *}$ & 0.374 & $0.001^{\star \star}$ & $0.002^{\star *}$ & $0.026^{\star *}$ & $0.003^{\star *}$ \\
\hline \multicolumn{8}{|c|}{ Plantations } \\
\hline AEZ 3 - AEZ 6 & $0.043^{\star \star}$ & $0.078^{*}$ & $0.028^{* \star}$ & 0.273 & 0.465 & 0.465 & 0.273 \\
\hline AEZ 3 - AEZ 8 & $0.064^{*}$ & $0.06^{*}$ & $0.064^{*}$ & $0.064^{*}$ & $0.064^{*}$ & 0.165 & 0.355 \\
\hline AEZ 6 - AEZ 8 & 0.466 & $0.014^{* *}$ & 0.716 & 0.544 & 0.332 & 0.332 & 0.393 \\
\hline
\end{tabular}

$\mathrm{NF}$ - natural forest, P - plantations, W - wasteland, AEZ - Agro-ecological zones, P (old) - Plantations older than 10 years, $P$ (new) - Plantations younger than 10 years. Differences between parameters based on land use were tested (two-tailed) with Mann-Whitney $U$ (non-parametric) for significance using SPSS. Significance level: ${ }^{* *} 0.05,{ }^{*} 0.1$

Table 6. A comparison of wasteland potential, in different agro-ecological zones (AEZ), for plantation activities based on field work cases.

\begin{tabular}{|c|c|c|c|c|c|c|c|c|}
\hline AEZ & $\begin{array}{l}\text { Climate } \\
\text { trend }\end{array}$ & $\begin{array}{l}\text { Wasteland } \\
\text { Availability } \\
\text { (in ha) }\end{array}$ & 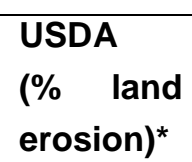 & GCOMAP & $\begin{array}{l}\text { Soil } \\
\text { quality }\end{array}$ & $\begin{array}{l}\text { AWC } \\
\mathrm{mm} / \mathrm{m}\end{array}$ & $\begin{array}{l}\text { Local } \\
\text { socio- } \\
\text { economy }\end{array}$ & $\begin{array}{l}\text { Local barriers } \\
\text { for } A / R \\
\text { establishment }\end{array}$ \\
\hline 3 & $\begin{array}{l}\text { Precipitation: } \\
\text { decrease } \\
\text { Temperature: } \\
\text { increase }\end{array}$ & 211355 & 3 & $\begin{array}{l}\text { Least } \\
\text { favourable }\end{array}$ & $\begin{array}{l}\text { Low } \\
\text { potential }\end{array}$ & 167 & $\begin{array}{l}\text { Available } \\
\text { land: } \mathrm{Y} \\
\text { Interest: } \\
\mathrm{Y}\end{array}$ & $\begin{array}{l}\text { Partly financial } \\
\text { and lack of } \\
\text { water }^{* *}\end{array}$ \\
\hline 6 & $\begin{array}{l}\text { Precipitation: } \\
\text { decrease (an }\end{array}$ & 341148 & 10 & $\begin{array}{l}\text { Most } \\
\text { favourable }\end{array}$ & $\begin{array}{l}\text { Most } \\
\text { suitable }\end{array}$ & 154 & $\begin{array}{l}\text { Available } \\
\text { private: } Y\end{array}$ & $\begin{array}{l}\text { Financial and } \\
\text { lack of water }\end{array}$ \\
\hline
\end{tabular}




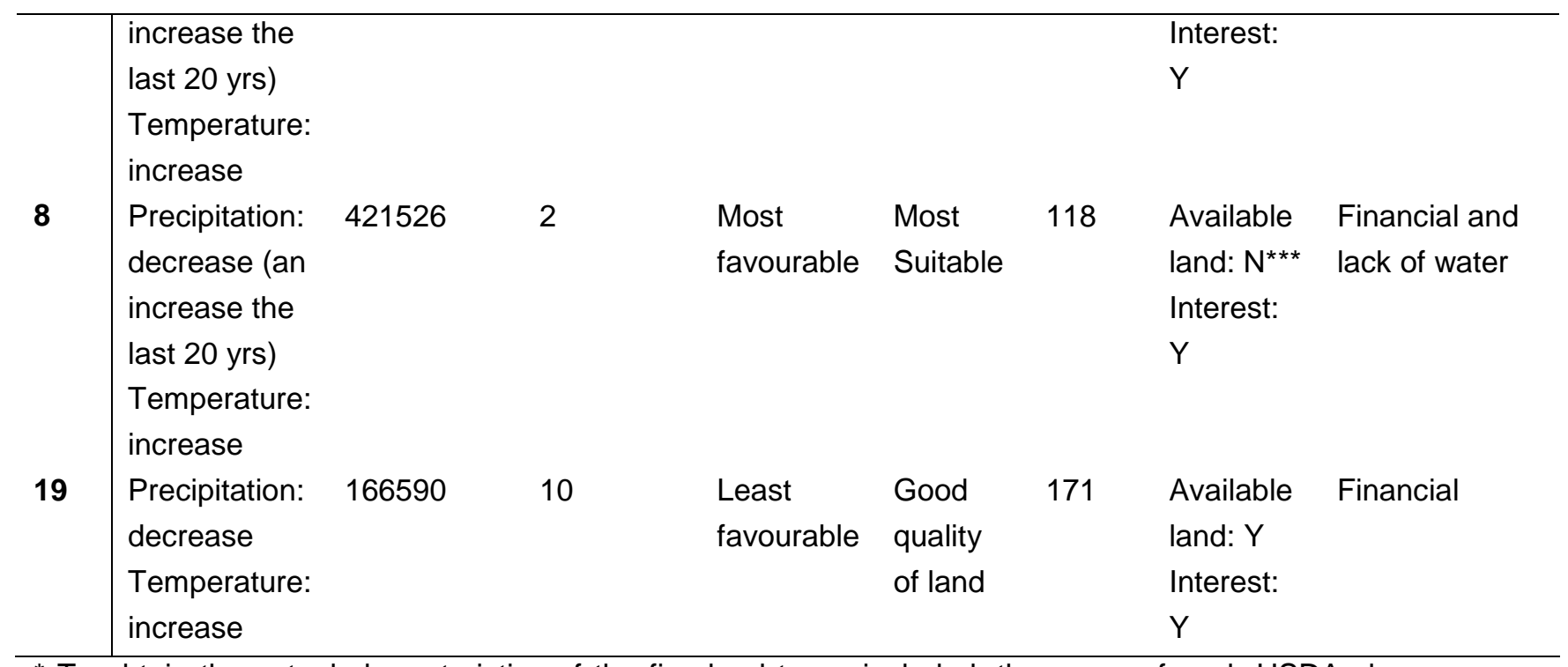

* To obtain the actual characteristics of the five land types included, the mean of each USDA class was divided by the number of plots investigated in each land type.

${ }^{* *}$ The interview response to local barriers were not unanimous in zone 3.

*** Only if there are financial means and the rate of return is higher from the $A / R$ activities than from the present land-use.

$\mathrm{Y}=$ yes $\mathrm{N}=$ no 